\title{
PENGURANGAN KADAR CO2 MENGGUNAKAN SPIRULINA PLATENSIS DALAM TUBULAR BIOREACTOR
}

\author{
Zainal Syam Arifin \\ Jurusan Kimia, Fakultas Matematika dan Ilmu Pengetahuan Alam, \\ Universitas Halu Oleo, Kendari, 93231 \\ e-mail: zhetha@gmail.com
}

\begin{abstract}
Increasing the population impact on increasing energy demand. On the other hand, the energy generation industry has been blamed as one of the contributors of carbon dioxide about $25 \%$ of total $\mathrm{CO}_{2}$ emissions worldwide. Meanwhile, the production of biogas, which aims to address the increasing need of energy, produces carbon dioxide in the range of 25-50\% by volume. To overcome this, a cheap method, optimum and efficient as well as environmentally friendly in reducing $\mathrm{CO}_{2}$ levels by using Spirulina platensis is needed. This research aims to created a mathematical models and found the optimum flow rate to reduced levels of $\mathrm{CO}_{2}$ by using Spirulina platensis. This study used a glass tubular bioreactor $(D=2.6 \mathrm{~cm})$ at a temperature of $30^{\circ} \mathrm{C}$ and irradiated with a fluorescent lamp Philips TL 36 Watt, color temperature: 6,200K cool daylight, light output: 2,600 lm, 72 $\mathrm{lm} / W$. Tubular reactor was placed in a box lined with silver foil walls on three sides. With mathematical models of tubular reactor, the reaction rate constants could be predicted. Based on calculations of data and graphs, optimum volumetric velocity could also be predicted. Variation of flowrate to observed the reduction rate of $\mathrm{CO}_{2} \mathrm{was} 0.25 \mathrm{~mL} / \mathrm{sec}$, $0.35 \mathrm{~mL} / \mathrm{sec}, \quad 0.5 \mathrm{~mL} / \mathrm{sec}, \quad 0.75 \mathrm{~mL} / \mathrm{sec}, \quad 1 \mathrm{~mL} / \mathrm{sec}$. Carbon source was $99.99 \%$ $\mathrm{CO}_{2}$.Observations of Spirulina growth was made on the flow rate of $0.25 \mathrm{~mL} / \mathrm{sec}$ at the initial levels of dry weight $2.1208 \mathrm{~g} / \mathrm{L}$. The results of this study indicated that the low flowratewas a more effective way to reduced carbon dioxide levels using Spirulina platensis $\left(k_{\mathrm{CO}_{2}}=2.82 \times 10^{-4} \mathrm{sec}^{-1}\right)$. The highest conversion was obtained at a volumetric flow rate of $0.25 \mathrm{~mL} / \mathrm{sec}$ and optimum speeds in the range of 0.3 to $0.4 \mathrm{~mL} / \mathrm{sec}$. The rate of incoming $\mathrm{CO}_{2}$ flux should be less than $0.047 \mathrm{~mL} / \mathrm{cm}^{2}$.detik. Specific Growth Rate $(\mu)$ of Spirulina platensis in this study was $2.56 \times 10^{-2}$ minute $^{-1}$.
\end{abstract}

Keywords: Spirulina platensis, a vertical tubular bioreactor, $\mathrm{CO}_{2}$ reduction

\begin{abstract}
ABSTRAK
Meningkatnya jumlah penduduk berdampak pada peningkatan kebutuhan energi. Di lain pihak, industri pembangkit energi dituding sebagai salah satu penyumbang karbon dioksida sekitar $25 \%$ dari total emisi $\mathrm{CO}_{2}$ di seluruh dunia. Disisi lain, produksi biogas yang bertujuan untuk mengatasi peningkatan kebutuhan energi justru menghasilkan karbon dioksida pada kisaran $25-50 \%$ volume. Untuk mengatasi hal ini, diperlukan metode yang murah, optimum dan efisien serta ramah lingkungan dalam mengurangi kadar $\mathrm{CO}_{2}$ dengan menggunakan spirulina platensis. Penelitian ini bertujuan membuat model matematik dan menemukan kecepatan aliran yang optimum untuk menurunkan kadar $\mathrm{CO}_{2}$ dengan menggunakan Spirulina Platensis. Penelitian ini menggunakan reaktor tubularterbuat dari kaca $(\mathrm{D}=2,6 \mathrm{~cm})$ pada suhu $30^{\circ} \mathrm{C}$ dan disinari dengan lampu TL Philips fluoresen 36 Watt, temperatur warna: $6.200 \mathrm{~K}$ cool daylight, light output: $2.600 \mathrm{~lm}, 72 \mathrm{~lm} / \mathrm{W}$. Reaktor tubular ditempatkan dalam kotak yang dilapisi dinding dengan kertas perak pada ketiga sisinya. Dengan model matematik reaktor tubular, dapat diprediksi konstanta kecepatan
\end{abstract}


reaksinya. Berdasarkan grafik hasil perhitungan data, kecepatan volumetrik optimumnya juga dapat diprediksi. Variasi flowrate yaitu $0,25 \mathrm{~mL} /$ detik, $0,35 \mathrm{~mL} / \mathrm{detik}, 0,5 \mathrm{~mL} / \mathrm{detik}$, 0,75 mL/detik, $1 \mathrm{~mL} /$ detik. Sumber karbon adalah $\mathrm{CO}_{2}$ 99,99\%. Pengamatan pertumbuhan Spirulina dilakukan pada flow rate $0,25 \mathrm{~mL} /$ detik dengan kadar berat kering mula - mula 2,1208 g/L. Hasil penelitian ini menunjukkan bahwa aliran lambat (flowrate rendah) merupakan cara yang lebih efektif dalam mengurangi karbon dioksida menggunakan spirulina platensis $\left(k_{\mathrm{CO}_{2}}=2,82 \times 10^{-4}\right.$ detik $\left.^{-1}\right)$. Nilai konversi tertinggi diperoleh pada kecepatan aliran volumetrik $0,25 \mathrm{~mL} /$ detik dan kecepatan optimumnya pada kisaran 0,3 $0,4 \mathrm{~mL} /$ detik. Laju flux $\mathrm{CO}_{2}$ masuk sebaiknya kurang dari $0,047 \mathrm{~mL} / \mathrm{cm}^{2}$.detik. Nilai Specific Growth Rate $(\mu)$ Spirulina Platensis dalam penelitian ini yaitu 2,56 $\times 10^{-2}$ menit $^{-1}$.

Kata Kunci: Spirulina platensis, reaktor tubular vertikal, pengurangan kadar $\mathrm{CO}_{2}$

\section{PENDAHULUAN}

Meningkatnya jumlah penduduk berdampak pada peningkatan kebutuhan energi. Di lain pihak, industri pembangkit energi dituding sebagai salah satu penyumbang karbon dioksida sekitar $25 \%$ dari total emisi $\mathrm{CO}_{2}$ di seluruh dunia. Disisi lain, produksi biogas yang bertujuan untuk mengatasi peningkatan kebutuhan energi justru menghasilkan karbon dioksida pada kisaran 25 - 50\% volume. Untuk mengatasi hal ini, diperlukan metode yang murah, optimum dan efisien serta ramah lingkungan dalam mengurangi kadar $\mathrm{CO}_{2}$ dengan menggunakan spirulina platensis.

Penelitian ini bertujuan membuat model matematik dan menemukan kecepatan aliran yang optimum untuk menurunkan kadar $\mathrm{CO}_{2}$ dengan menggunakan Spirulina Platensis. Penelitian ini menggunakan reaktor tubular vertikal pada suhu $30^{\circ} \mathrm{C}$ dan disinari dengan lampu TL Philips fluoresen 36 Watt, temperatur warna: $6.200 \mathrm{~K}$ cool daylight, light output: $2.600 \mathrm{~lm}, 72 \mathrm{~lm} / \mathrm{W}$. Reaktor tubular ditempatkan dalam kotak yang dilapisi dinding dengan kertas perak pada ketiga sisinya. Dengan model matematik reaktor tubular, dapat diprediksi konstanta kecepatan reaksinya. Berdasarkan grafik hasil perhitungan data, kecepatan volumetrik optimumnya juga dapat diprediksi. Variasi flowrate yaitu $0,25 \mathrm{~mL} /$ detik, $0,35 \mathrm{~mL} /$ detik, 0,5 $\mathrm{mL} /$ detik, $0,75 \mathrm{~mL} /$ detik, $1 \mathrm{~mL} /$ detik.
Kadar berat kering spirulina adalah 2,1204 gram/L. Sumber karbon adalah $\mathrm{CO}_{2}$ 99,99\%.

Beberapa penelitian pada mikroalga Spirulina Platensis telah banyak dilakukan diantaranya adalah pengaruh konsumsi $\mathrm{CO}_{2}$, pengaruh cahaya, temperatur, dan $\mathrm{pH}$ terhadap pertumbuhan Spirulina oleh vonshak.

Arthrospira platensis adalah anggota phylum Cyanobacteria, yaitu kelompok bakteri yang sanggup memperoleh energi melalui fotosintesis dan memiliki warna hijau kebiruan (Fedor, 2011).

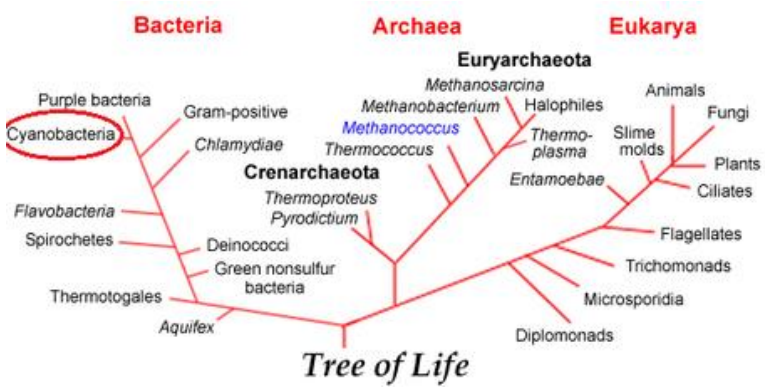

Gambar 1. Tree of Life Spirulina Platensis (Fedor, 2011)

Fotosintesis adalah suatu proses metabolisme di mana semua organisme photoautotrophic, yaitu bakteri fotosintetik, cyanobacteria dan tanaman tingkat tinggi, dapat mengubah energi cahaya menjadi energi kimia dalam bentuk karbohidrat. Selama fotosintesis oksigenik pada cyanobacteria dan 
tumbuhan tingkat tinggi, energi cahaya digunakan untuk mengangkut elektron dari air ke $\mathrm{NADP}^{+}$dengan evolusi yang serupa dengan oksigen. ATP dan NADPH yang dihasilkan selama proses berbasis cahaya tersebut kemudian digunakan untuk konversi enzimatik $\mathrm{CO}_{2}$ di atmosfer menjadi karbohidrat.

$6 \mathrm{CO}_{2}+6 \mathrm{H}_{2} \mathrm{O} \rightarrow \mathrm{C}_{6} \mathrm{H}_{12} \mathrm{O}_{6}+6 \mathrm{O}_{2}$ (Pers.1)

Lokasi dari reaksi fotosintesis cahaya adalah pada membran tilakoid (Mohanty, Srivastava, \& Krishna, 2002).

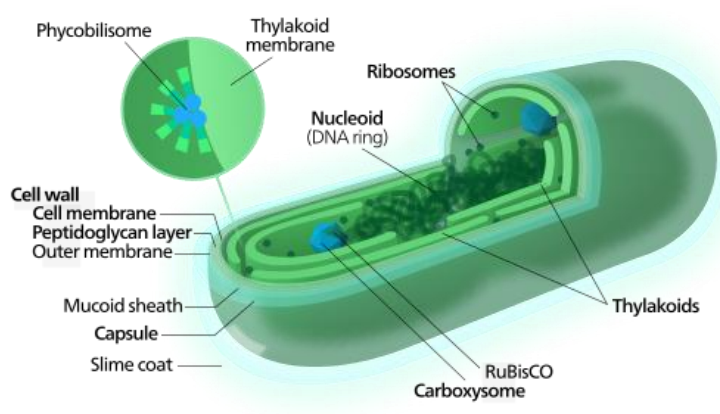

Gambar 2. Sebuah sel Cyanobacteria (Kelvinsong, 2013)

Spirulina mengkonsumsi $\mathrm{CO}_{2}$ (fiksasi karbondioksida) dalam proses fotosintesis terdiri dari dua tahap yang disebut reaksi terang, yang membutuhkan cahaya dan melibatkan pemecahan air serta pelepasan oksigen, dan reaksi gelap atau siklus Calvin, yang mengubah karbon dioksida menjadi gula (Taiz \& Zeiger, 2002)

Spirulina Maxima dan Spirulina Platensis adalah cyanobacteria berbentuk plankton yang membentuk populasi besar di perairan daerah tropis dan subtropis yang dicirikan oleh tingginya kadar karbonat dan bikarbonat serta $\mathrm{pH}$ yang tinggi (sampai 11). Jika Spirulina platensis tampaknya menjadi spesies yang lebih luas terutama ditemukan di Afrika, juga di Asia dan Amerika Selatan, namun Spirulina maxima secara esensial tampaknya terbatas sampai ke Amerika Tengah. Spesies yang terakhir ini merupakan komponen utama dari fitoplankton danau Texcoco, yang dapat dianggap sebagai habitat asli spesies ini. Demikian pula, danau garam alkali dari zona setengah gurun Sudan-Sahel, dengan pusat gempa di danau Chad, dan yang berasal dari lembah Rift, didominasi oleh bunga air S. platensis, dapat dianggap sebagai titik awal spesies ini (Tomaselli, 2002).

\section{Permodelan matematik}

Aliran gas karbon dioksida mengikuti model reaktor tubular.

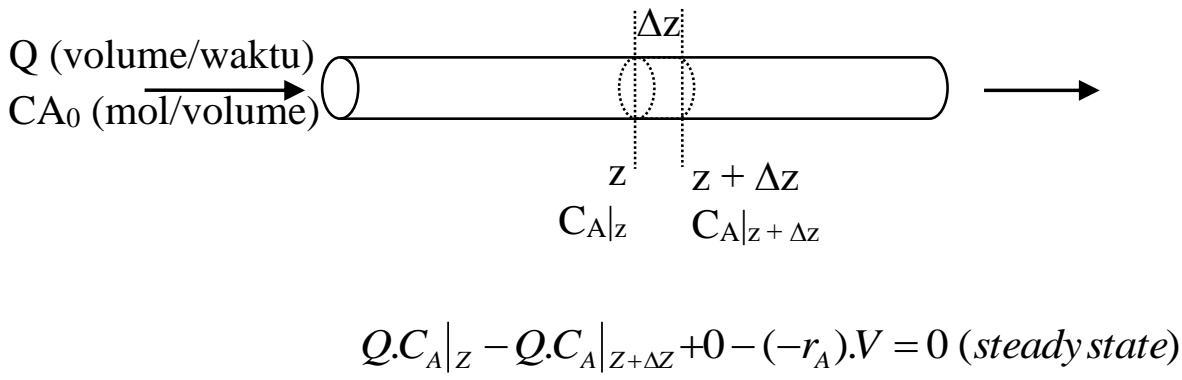

$$
\text { dimana, } V=\pi \cdot r^{2} \cdot \Delta Z=\frac{1}{4} \cdot \pi \cdot D^{2} \cdot \Delta Z, \text { sehingga } \frac{\left.C_{A}\right|_{Z+\Delta Z}-\left.C_{A}\right|_{Z}}{\Delta Z}=-\left(-r_{A}\right) \frac{1}{4} \cdot \pi \cdot \frac{D^{2}}{Q}
$$

Untuk $\lim _{\Delta Z \rightarrow 0} \frac{\left.C_{A}\right|_{Z+\Delta Z}-\left.C_{A}\right|_{Z}}{\Delta Z}$, diperoleh 


$$
\frac{d C_{A}}{d C_{Z}}=-\left(-r_{A}\right) \frac{1}{4} \cdot \pi \cdot \frac{D^{2}}{Q} \quad(\text { Pers. } 2)
$$

Ada 2 kemungkinan order reaksi:

1. Order reaksi $=1(\mathrm{n}=1)$ maka

$\int_{C_{A}=C_{A_{0}}}^{C_{A}=C_{A}} \frac{d C_{A}}{C_{A}{ }^{n}}=-\frac{k_{A} \pi D^{2}}{4 Q} \int_{Z=0}^{Z=Z} d Z$ $-r_{A}=k_{A} . C_{A}$

2. Order reaksi $\neq 1(\mathrm{n} \neq 1)$ maka $-r_{A}=k_{A} \cdot C_{A}{ }^{n}$ $\frac{1}{1-n} C_{A}^{1-n}=\frac{1}{1-n} C_{A_{0}}^{1-n}-\frac{k_{A} \pi D^{2} Z}{4} \cdot \frac{1}{Q}$ (pers. 4)

(i). Untuk Reaksi Order 1, maka $-r_{A}=k_{A} \cdot C_{A}$ :

$C_{A}=$ kadar karbon dioksida keluar pada posisi $Z$, (mol/L)

$\frac{d C_{A}}{d Z}=-\left(k_{A} \cdot C_{A}\right) \frac{\pi \cdot D^{2}}{4 Q}$

$C_{A_{0}}=$ kadar karbon dioksida masuk pada posisi $Z=0,(\mathrm{~mol} / \mathrm{L})$

$Q=$ flow rate, $(\mathrm{mL} / \mathrm{detik})$

$\mathrm{D}=$ diameter reaktor, dan

$\int_{C_{A}=C_{A_{0}}}^{C_{A}=C_{A}} \frac{d C_{A}}{C_{A}}=-\frac{k_{A} \pi D^{2}}{4 Q} \int_{Z=0}^{Z=Z} d Z$

$\mathrm{Z}$ = panjang reaktor, dapat dinyatakan sebagai volume reaktor tubular $V_{r}=\frac{\pi D^{2} Z}{4}(\mathrm{~mL})$.

$\ln C_{A}=\ln C_{A_{0}}-\frac{k_{A} \pi D^{2} Z}{4} \cdot \frac{1}{Q}$ (pers. 3)

Pertumbuhan Spirulina mengikuti

(ii). Untuk Reaksi Order $n \neq 1$, maka

$$
\begin{gathered}
-r_{A}=k_{A} \cdot C_{A}{ }^{n} \\
\frac{d C_{A}}{d Z}=-\left(k_{A} \cdot C_{A}{ }^{n}\right) \frac{\pi \cdot D^{2}}{4 Q}
\end{gathered}
$$

model reaktor batch dengan orleters rłąksi $\mathrm{n}=1$ dan Nilai Specific Growth Rate $(\mu)$ Spirulina dapat dicari dengan persamaan sebagai berikut dibawah ini.

$$
\begin{aligned}
& \ln C_{S_{P}}=\ln C_{S_{P_{0}}}+\mu . t \text { (pers. 5) } \\
& C_{S_{P}}= \text { kadar sprirulina pada setiap waktu } \\
& \mathrm{t},(\mathrm{g} / \mathrm{L}) \\
& C_{S_{P_{0}}}= \text { kadar sprirulina mula-mula pada } \\
& \text { waktu } \mathrm{t}=0,(\mathrm{~g} / \mathrm{L})
\end{aligned}
$$

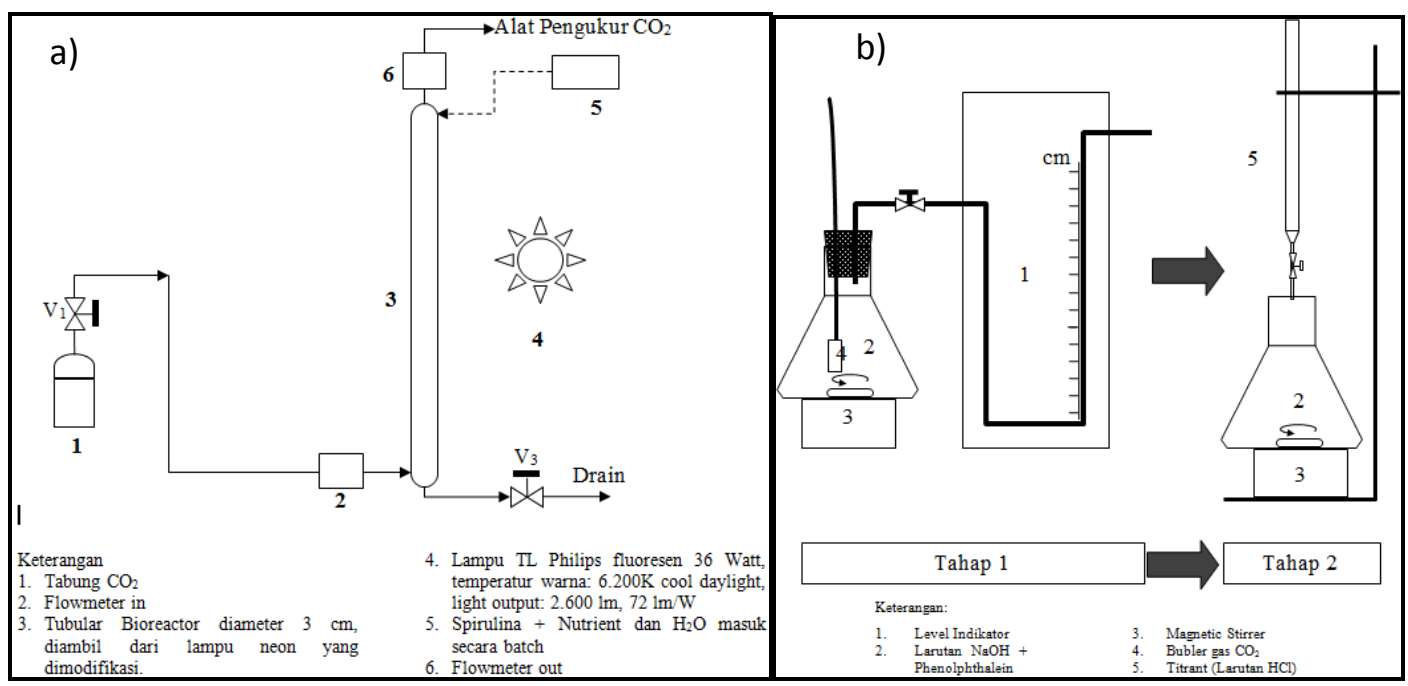

Gambar 3. Rangkaian Peralatan Tubular bioreactor dan Pengukuran $\mathrm{CO}_{2}$ 


\section{METODE PENELITIAN \\ Bahan Penelitian}

Bahan-bahan: Spirulina Platensis, gas karbon dioksida 99,99\%, air laut steril, pupuk walne, sertaLarutan $\mathrm{NaOH}$ $0,01 \mathrm{~N}$ dan $\mathrm{HCl} 0,01 \mathrm{~N}$.

\section{Alat Penelitian}

Skema alat penelitian dapat dilihat pada Gambar 3.

\section{Prosedur Penelitian}

1. Pembiakan Spirulina Platensis

Sebanyak $200 \mathrm{~mL}$ bibit Spirulina Platensis ditambahkan $800 \mathrm{~mL}$ air laut steril sehingga volumenya menjadi 1000 $\mathrm{mL}$. Sebanyak $1 \mathrm{~mL}$ pupuk Walne dimasukkan ke dalam kolom pembiakan tersebut. Selanjutnya di aerasi dalam ruangan indoor berumur 4 hari dan diberi cahaya lampu daylight.

2. Variasi flow rate

a). Terlebih dahulu ke dalam reaktor dimasukkan larutan media spirulina (hanya berisi media air dan nutrien spirulina, tanpa kehadiran Spirulina) dengan volume $500 \mathrm{~mL}$. Kemudian lampu daylight dinyalakan agar diperoleh kondisi lingkungan (suhu) yang sama ketika dilakukan dengan kehadiran Spirulina. Kran $\mathrm{CO}_{2}$ dibuka secara perlahan (menggunakan regulator) sampai flowrate tertentu (Q1). Kemudian gas $\mathrm{CO}_{2}$ yang keluar ditampung dalam alat pengukur $\mathrm{CO}_{2}$ (Gambar 3.1b). Percobaan diulangi untuk flowrate yang lain (Q2, Q3, dst).Suhu dalam reaktor konstan $30^{\circ} \mathrm{C}$.

b). Cara yang sama dengan langkah (a) di atas namun spirulina telah dimasukan dalam reaktor.

\section{Flow rate tetap}

Dipilih salah satu flowrate yang sudah pernah dilakukan sebelumnya yaitu $0,25 \mathrm{~mL} /$ detik. Sama seperti proses $2 \mathrm{~b}$ di atas namun pada setiap selang waktu 5 menit selama 1 jam diambil sampel melalui drain dan diukur kadar berat keringnya.

4. Cara Pengukuran Karbon Dioksida dengan Menggunakan Titrasi

Jumlah mol $\mathrm{CO}_{2}$ yang dikonsumsi Spirulina setiap detik $(\mathrm{t}=5)$ adalah

$$
=\left(\frac{\left(N_{H C l} \cdot V_{H C l}\right)_{\text {outlet }}-\left(N_{H C l} \cdot V_{H C l}\right)_{\text {inlet }}}{t}\right) \text { mol/detik }
$$

\section{HASIL DAN PEMBAHASAN}

\section{Pengaruh Kecepatan Volumetrik Karbon Dioksida terhadap Laju Konversi}

Gas $\mathrm{CO}_{2}$ dialirkan secara kontinyu dalam tubular bioreaktor. Kadar $\mathrm{CO}_{2}$ masuk dan kadar $\mathrm{CO}_{2}$ keluar diukur dengan cara titrasi, dan hasilnya disajikan dalam Tabel 1.

Tabel 1. Kadar $\mathrm{CO}_{2}$ yang keluar reaktor pada berbagai flowrate

\begin{tabular}{ccc}
\hline $\mathrm{Q}$ & $C_{\mathrm{CO}_{20}}$ & $C_{\mathrm{CO}_{2}}$ \\
\hline $0,25 \mathrm{~mL} /$ detik & $1,9847 \mathrm{~mol} / \mathrm{L}$ & $1,7327 \mathrm{~mol} / \mathrm{L}$ \\
$0,35 \mathrm{~mL} /$ detik & $1,9847 \mathrm{~mol} / \mathrm{L}$ & $1,8161 \mathrm{~mol} / \mathrm{L}$ \\
$0,50 \mathrm{~mL} /$ detik & $1,9847 \mathrm{~mol} / \mathrm{L}$ & $1,8694 \mathrm{~mol} / \mathrm{L}$ \\
$0,75 \mathrm{~mL} /$ detik & $1,9847 \mathrm{~mol} / \mathrm{L}$ & $1,9078 \mathrm{~mol} / \mathrm{L}$ \\
$1,00 \mathrm{~mL} /$ detik & $1,9847 \mathrm{~mol} / \mathrm{L}$ & $1,9274 \mathrm{~mol} / \mathrm{L}$ \\
\hline
\end{tabular}


Tabel 2. Konsumsi $\mathrm{CO}_{2}$ pada berbagai flowrate

\begin{tabular}{ccc}
\hline $\mathrm{Q}(\mathrm{mL} /$ detik $)$ & Laju $\mathrm{CO}_{2}\left(\mathrm{~mL} / \mathrm{cm}^{2}\right.$. detik $)$ & $\Delta \mathrm{C}_{\mathrm{A}}(\mathrm{mol} / \mathrm{L})$ \\
\hline 0,25 & 0,0117 & 0,2520 \\
0,35 & 0,0165 & 0,1686 \\
0,50 & 0,0235 & 0,1153 \\
0,75 & 0,0353 & 0,0769 \\
1,00 & 0,0471 & 0,0573 \\
\hline
\end{tabular}

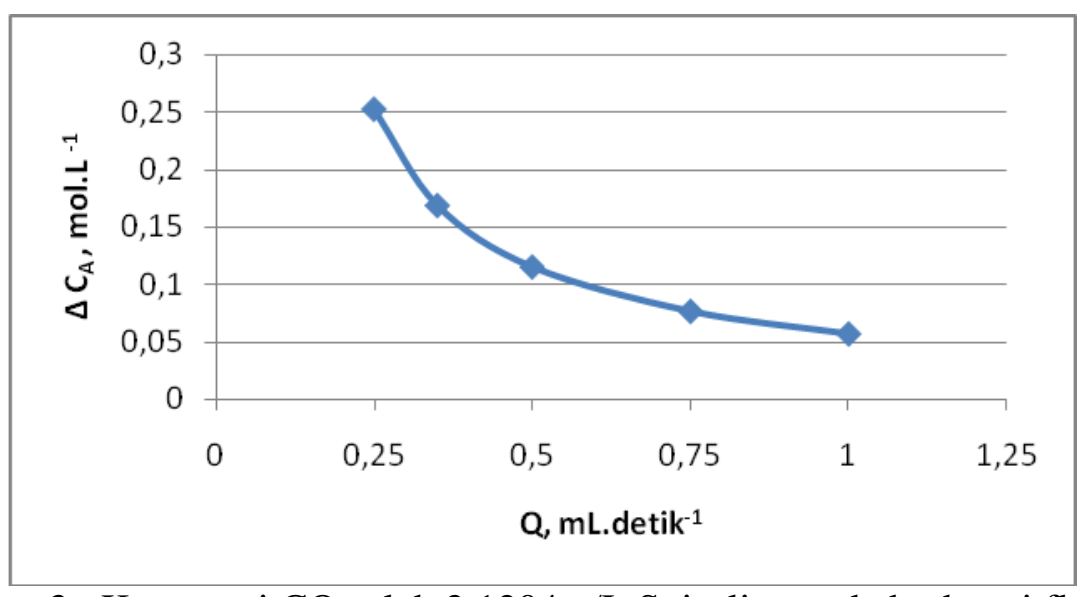

Gambar 3. Konsumsi $\mathrm{CO}_{2}$ oleh 2,1204 g/L Spirulina pada berbagai flowrate

Dari Gambar 3, laju konversi $\mathrm{CO}_{2}$ tertinggi diperoleh pada laju aliran volumetrik $\mathrm{CO}_{2}$ terendah yaitu pada 0,25 $\mathrm{mL} /$ detik. Hal ini disebabkan, kecepatan flux $\mathrm{CO}_{2}(\mathrm{Q} / \mathrm{A})$ semakin rendah pada kecepatan volumetrik yang lebih rendah, sehingga waktu tinggal $\mathrm{CO}_{2}$ dalam reaktor pun akan menjadi lebih lama. Pada kecepatan volumetrik $1 \mathrm{~mL} /$ detik, laju konversi sudah mulai menampakkan laju yang konstan yaitu sekitar 0,05 mol/detik.

Ini berarti, dalam kolom reaktor vertikal tanpa bahan isian, disarankan laju flux $\mathrm{CO}_{2}$ masuk sebaiknya tidak boleh melebihi angka 0,047 mL.cm ${ }^{-2}$.detik.

Berdasarkan perhitungan penyelesaian persamaan 3 dan 4, order reaksi adalah $\mathrm{n}=1$ dan diperoleh nilai kinetika reaksi $\left(\mathrm{k}_{\mathrm{A}}\right)$ pengurangan karbon dioksida adalah $k_{\mathrm{CO}_{2}}=2,82 \times 10^{-4}$ detik $^{-1}$. Nilai ini sangat kecil sehingga tidak cocok diterapkan untuk mengurangi $\mathrm{CO}_{2}$ dengan flowrate besar.

Berdasarkan Gambar 5, flowrate optimumnya diperoleh pada kisaran $0,3-$ $0,4 \mathrm{~mL} /$ detik.

\section{Pertumbuhan Spirulina pada flow rate tetap}

Untuk mengamati pertumbuhan spirulina, proses dilakukan pada flowrate $\mathrm{CO}_{2}$ tetap yaitu $0,25 \mathrm{~mL} /$ detik dan setiap selang waktu 5 menit dilakukan pengukuran berat kering spirulina, hasilnya disajikan dalam Tabel 5. Kadar berat kering spirulina mula - mula adalah 2,1208 g/L.

Tabel 3. Kadar $\mathrm{CO}_{2}$ outlet dengan kadar spirulina awal 2,1204 gram/L pada berbagai flowrate

\begin{tabular}{cccccc}
\hline $\mathbf{Q}(\mathrm{mL} /$ detik $)$ & 0,25 & 0,35 & 0,50 & 0,75 & 1,00 \\
\hline$C_{\mathrm{CO}_{2}}(\mathrm{~mol} / \mathrm{L})$ & 1,7327 & 1,8161 & 1,8694 & 1,9078 & 1,9274 \\
\hline
\end{tabular}




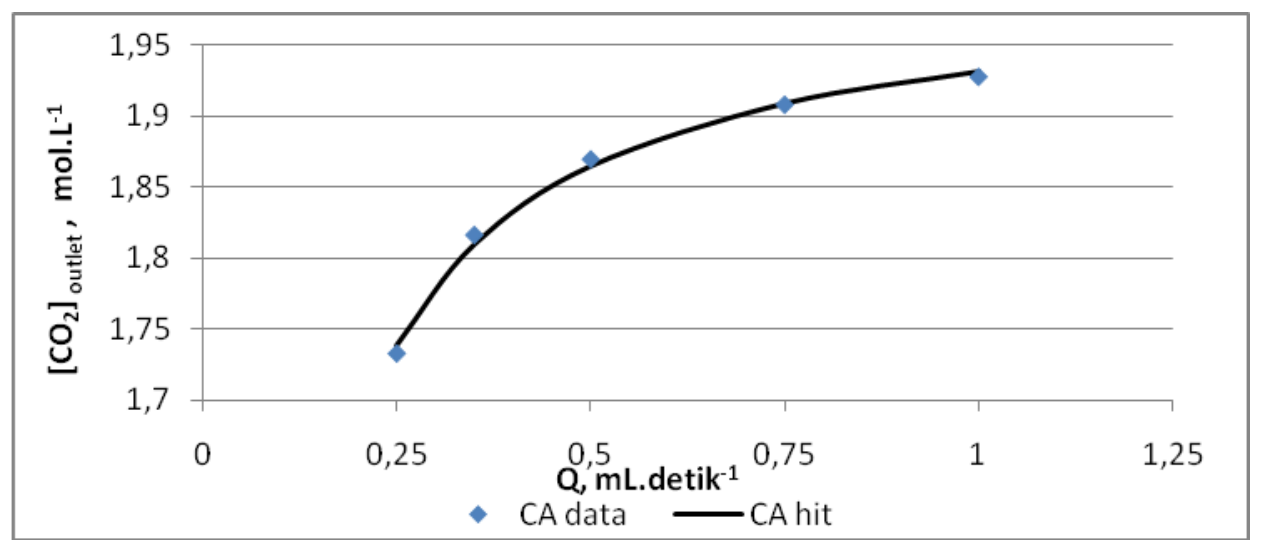

Gambar 4. Variasi kadar Karbon dioksida yang keluar reaktor pada berbagai Flow rate dengan kadar spirulina awal 2,1204 gram/L

Tabel 4. Konversi $\mathrm{CO}_{2}$ dengan kadar spirulina awal 2,1204 gram/L pada berbagai flowrate

\begin{tabular}{|c|c|c|c|c|c|}
\hline $\mathrm{Q}$ (mL/detik) & 0,25 & 0,35 & 0,50 & 0,75 & 1,00 \\
\hline$\Delta \mathrm{F}_{\mathrm{A}}(\mathrm{mol} /$ detik $)$ & $6,30 \times 10^{-5}$ & $5,90 \times 10^{-5}$ & $5,76 \times 10^{-5}$ & $5,76 \times 10^{-5}$ & $5,73 \times 10^{-5}$ \\
\hline
\end{tabular}

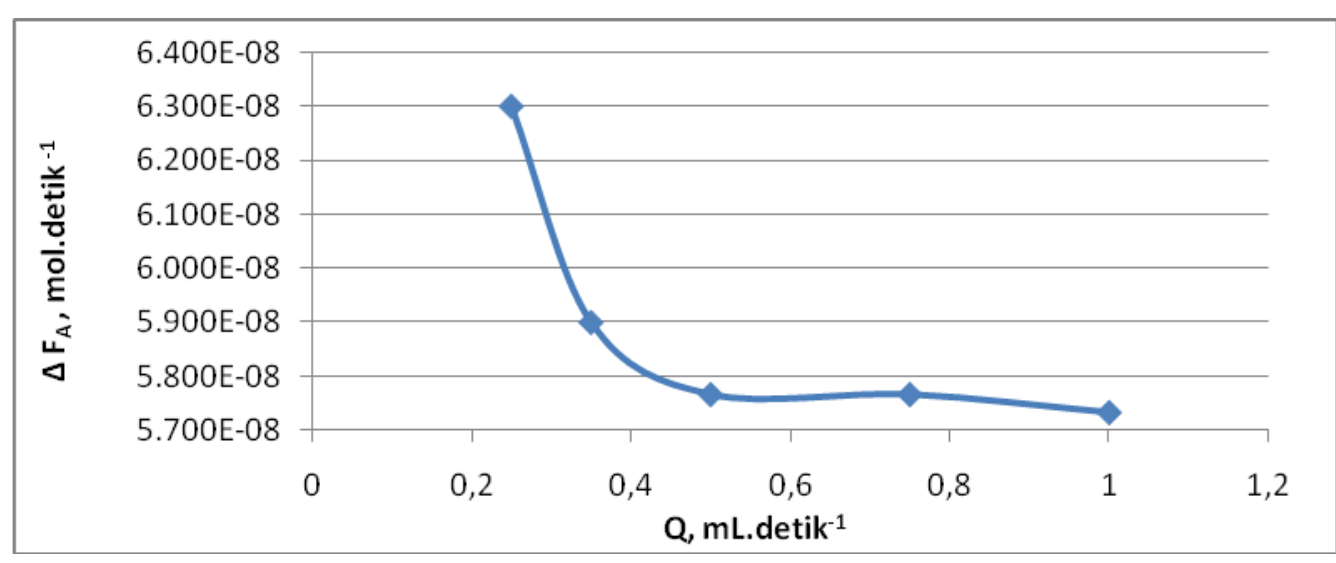

Gambar 5. Konversi $\mathrm{CO}_{2}$ dengan kadar spirulina awal 2,1204 gram/L pada berbagai flowrate

Tabel 5. Kadar Spirulina pada setiap selang waktu pada flowrate $0,25 \mathrm{~mL} /$ detik

\begin{tabular}{ccccccccccc}
\hline $\mathrm{t}$ (menit) & 0 & 5 & 10 & 15 & 20 & 25 & 30 & 40 & 50 & 60 \\
\hline $\mathrm{C}_{\mathrm{Sp}}(\mathrm{g} / \mathrm{L})$ & 2,1208 & 3,0328 & 3,9471 & 4,8632 & 5,7810 & 6,6995 & 7,4793 & 8,8263 & 9,9268 & 10,8579
\end{tabular}

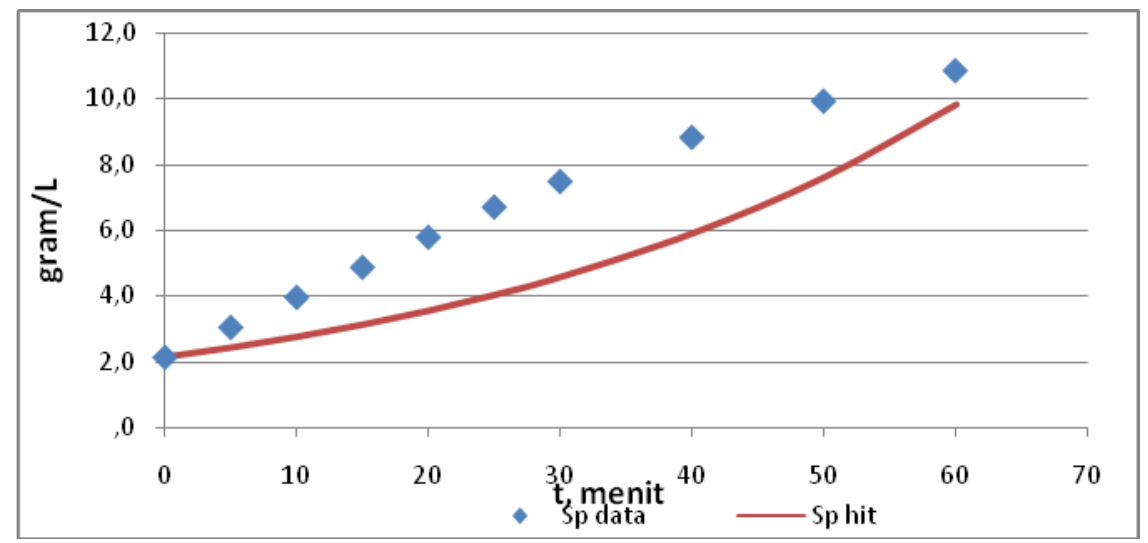

Gambar 6. Berat Spirulina pada setiap waktu dengan kadar mula-mula 2,1208 g/L dan flowrate tetap $0,25 \mathrm{~mL} /$ detik 
Dengan metode linier penyelesaian persamaan 5, dapat dihitung nilai specific growth rate $(\mu)$ pertumbuhan spirulina yaitu $\mu=2,56 \times 10^{-2}$ menit $^{-1}$. Pada flow rate, $\mathrm{Q}=0,25 \mathrm{~mL} /$ detik, dari Tabel 4 diperoleh,

$$
\Delta F_{A}=6,30 \times 10^{-5} \frac{\mathrm{mol}}{\text { detik }}
$$

Jumlah $\mathrm{O}_{2}$ yang dihasilkan setara dengan $\Delta \mathrm{F}_{\mathrm{A}} \quad$ (persamaan 1), sehingga $F_{O_{2}}=\Delta F_{A}=6,30 \times 10^{-5} \frac{\mathrm{mol}}{\text { detik }}$.

Diasumsikan, laju konversi tidak berkurang sampai waktu tertentu. Pada initial condition, jumlah oksigen yang diproduksi adalah,

$$
C_{O_{2}}=\frac{6,30 \times 10^{-5} \frac{\mathrm{mol}}{\mathrm{detik}}}{0,25 \frac{\mathrm{mL}}{\text { detik }}}=8064 \mathrm{mg} / \mathrm{L} \text {. }
$$

Menurut Torzillo, jika jumlah oksigen lebih dari $30 \mathrm{mg} / \mathrm{L}$ akan berpengaruh secara negatif terhadap pertumbuhan dan sintesis protein Spirulina. Kadar $\mathrm{O}_{2}$ yang dihasilkan yaitu $8064 \mathrm{mg} / \mathrm{L}$, berarti melebihi $30 \mathrm{mg} / \mathrm{L}$. Berdasarkan Gambar 6, semakin lama waktu yang dibutuhkan, semakin berkurang kecepatan peningkatan kadar Spirulina. Spirulina Platensis sanggup bertahan hidup sampai 14 hari, masa 60 menit seharusnya masih merupakan masa dalam fase pertumbuhan. Namun grafik di atas tampaknya menunjukkan penurunan sintesis enzimatik. Hal ini disebabkan disamping berkurangnya kadar Nitrogen sebagai salah satu unsur terpenting dalam pembentukan protein (tidak mendapatkan suplai nitrogen dari atmosfir dan tidak mendapatkan tambahan nutrisi) juga disebabkan meningkatnya kadar oksigen dalam reaktor. Meskipun penurunan ini hanya berlangsung secara perlahan sebagaimana yang ditunjukkan pada grafik tersebut di atas, namun secara teoritis, tren kurva pertumbuhan seharusnya mengikuti kurva perhitungan ( $\mathrm{sp}_{\text {hit }}$ ).
Laju pertumbuhan Spirulina lebih tinggi dibandingkan penelitian vonshak, hal ini disebabkan penelitian vonshak menggunakan $\mathrm{CO}_{2}$ atmosfir, sedangkan dalam penelitian ini, Spirulina menggunakan sumber karbon dari $\mathrm{CO}_{2}$ yang kadarnya lebih tinggi (100\%).

\section{KESIMPULAN}

Berdasarkan hasil penelitian dan pembahasan, dapat dismpulkan:

1. Aliran lambat (flowrate rendah) merupakan cara yang efektif dalam mengurangi kadar $\mathrm{CO}_{2}$ dengan memanfaatkan spirulina platensis dalam tubular reaktor vertikal berdiameter $3 \mathrm{~cm}$.

2. Pengurangan kadar $\mathrm{CO}_{2}$ dengan nilai konversi tertinggi diperoleh pada kecepatan alir volumetrik 0,25 $\mathrm{mL} /$ detik dan kecepatan optimumnya pada kisaran $0,3-0,4 \mathrm{~mL} /$ detik.

3. Orde reaksi dalam penelitian ini adalah $\mathrm{n}=1$. Berdasarkan nilai konstanta kinetika reaksi yang sangat kecil yaitu $k_{\mathrm{CO}_{2}}=2,82 \times 10^{-4}$ detik $^{-1}$, spirulina tidak cocok diterapkan untuk mengurangi karbon dioksida pada laju aliran yang besar. Spirulina cocok diterapkan untuk mengurangi jumlah $\mathrm{CO}_{2}$ pada proses pembuatan biogas yang laju produksinya lebih kecil.

4. Dalam kolom bioreaktor vertikal dengan tanpa bahan isian, laju flux $\mathrm{CO}_{2}$ masuk sebaiknya kurang dari 0,047 mL.cm ${ }^{-2}$.detik. Semakin rendah laju flux $\mathrm{CO}_{2}$ masuk $\left(<<0,047\right.$ mL.cm ${ }^{-2}$.detik), semakin tinggi konversi $\mathrm{CO}_{2}$ yang diperoleh.

5. Specific Growth Rate $(\mu)$ Spirulina Platensis dalam penelitian ini adalah $\mu=2,56 \times 10^{-2}$ menit $^{-1}$. Nilai ini masih dipengaruhi oleh kadar oksigen yang berlebihan dalam reaktor. 
DAFTAR PUSTAKA

1. Fedor, K. (2011, 10 30). Arthrospira platensis. Bio203. University of Wisconsin-La Crosse.

2. Kelvinsong. (2013, 01 23). File:Cyanobacterium-inline.svg.

Dipetik 04 10, 2014, dari Wikimedia Commons:

http://commons.wikimedia.org/wiki/F ile:Cyanobacterium-inline.svg

3. Mohanty, P., Srivastava, M., \& Krishna, K. B. (2002). The Photosynthetic Apparatus of Spirulina: Electron Transport and Energy Transfer. In A. Vonshak (Ed.), Spirulina platensis (Arthrospira): Physiology, Cellbiology and Biotechnology. Taylor \& Francis.

4. Taiz, L., \& Zeiger, E. (2002). Plant Physiology (3rd ed.). Sunderland: Sinauer Associates.
5. Tomaselli, L. (2002). Morphology, Ultrastructure and Taxonomy of Arthrospira (Spirulina) maxima and Arthrospira (Spirulina) platensis. Dalam A. Vonshak (Penyunt.), Spirulina platensis (Arthrospira): Physiology, Cell-biology and Biotechnology. Taylor \& Francis eLibrary.

6. Torzillo, G., Giovanetti, L., Bocci, F., \& Materassi, R. (1984). Effect of oxygen concentration on the protein content of Spirulina biomass. Biotechnol. Bioeng, 26, 1134.

7. Vonshak, A. (2002). Spirulina: Growth, Physiology and Biochemistry. In A. Vonshak (Ed.), Spirulina platensis (Arthrospira): Physiology, Cell-biology and Biotechnology. Taylor \& Francis eLibrary. 